\title{
Analisis Pengendalian Intern Piutang Dalam Meminimalisir Piutang Tak Tertagih Pada CV Bumi Tiara Abadi Palembang
}

\author{
Andri Eko Putra \\ Fakultas Ekonomi Universitas PGRI Palembang,
}

\begin{abstract}
ABSTRAK
Penelitian ini bertujuan untuk mengetahui sistem pengendalian intern piutang dalam meminimalisir piutang tak tertagih pada CV Bumi Tiara Abadi. Metode penelitian yang digunakan adalah deskriptif kuantitatif dengan data sekunder. Teknik pengumpulan data adalah dokumentasi dan studi pustaka. Populasi adalah daftar piutang dan piutang tak tertagih pada CV Bumi Tiara Abadi, sedangkan sampel adalah daftar piutang dan piutang tak tertagih pada CV Bumi Tiara Abadi dari tahun 2013 sampai dengan 2015. Hasil penelitian menunjukkan sistem pengendalian intern atas piutang pada CV Bumi Tiara Abadi belum cukup baik karena perusahaan hanya membuat kartu piutang dalam pencatatan piutang, perusahaan tidak meminta dan menggunakan rekening koran, perusahaan tidak membuat bukti kwitansi. Rekomendasi bagi perusahaan agar menerapkan sistem pencatatan piutang baik sehingga piutang perusahaan dapat terdata dan tertagih tepat waktu.
\end{abstract}

Kata Kunci : Pengendalian Intern atas Piutang

\section{PENDAHULUAN}

Dunia usaha di Indonesia saat ini sudah semakin berkembang, bisa dilihat dari semakin banyaknya berdiri usaha-usaha baru yang didirikan oleh masyarakat. Salah satu aspek penting pada suatu perusahaan adalah sistem pengendalian intern, karena suatu perusahaan tidak dapat berjalan dengan baik tanpa adanya sistem pengendalian intern yang baik.

Strategi yang digunakan suatu perusahaan untuk menarik konsumen, salah satunya adalah dengan cara menjual produk secara kredit. Melalui penjualan tersebut perusahaan memperoleh pendapatan secara tidak langsung (piutang). Sehingga perusahaan mendapatkan sebuah risiko mengenai kepastian pembayaran yang akan dilakukan dikemudian hari. Adanya piutang dalam kegiatan perusahaan memungkinkan terjadinya keadaan dimana piutang tersebut tidak dilunasi (bed debt). Dalam transaksi penjualan kredit, jika order dari pelanggan telah dipenuhi dengan pengiriman barang atau jasa untuk jangka waktu tertentu perusahaan memiliki piutang kepada
pelanggannya. Pengendalian intern meliputi struktur organisasi perusahaan yang dikoordinasikan untuk menjaga kekayaan perusahaan, mengecek ketelitian dan keandalan data akuntansi, mendorong efesiensi dan mendorong agar dipenuhinya kebijaksanaan akuntansi pada penjualan kredit untuk meningkatkan pengendalian intern dalam suatu perusahaan yang menjadi objek penelitian. Pengendalian intern yang memadai tidak menjamin bahwa semua penyimpangan atas tindakan yang merugikan perusahaan dapat dihindarkan sama sekali, tetapi kemungkinan-kemungkinan tersebut diusahakan dapat seminimal mungkin.

Tujuan perusahaan adalah mencapai laba maksimal dengan menekan biaya-biaya operasional seminimal mungkin. Salah satu sumber laba adalah melalui penjualan barang dan jasa yang diproduksi perusahaan. Perusahaan harus mempunyai strategi untuk menarik minat konsumen memilih barang yang diproduksi. Bentuk strategi yang 
digunakan suatu perusahaan untuk menarik konsumen, salah satunya adalah dengan cara menjual produk secara kredit. Melalui penjualan tersebut perusahaan memperoleh pendapatan secara tidak langsung (piutang), namun strategi menjual secara kredit dapat menimbulkan risiko piutang tak tertagih atau penundaan pendapatan. Piutang dalam kegiatan perusahaan memungkinkan terjadinya keadaan dimana piutang tersebut tidak dilunasi (bed debt).

Dalam transaksi penjualan kredit, jika order dari pelanggan telah dipenuhi dengan pengiriman barang atau jasa untuk jangka waktu tertentu maka dikatakan perusahaan memiliki piutang kepada pelanggannya. Secara otomatis dana perusahaan tertahan pada konsumen, dan mengurangi pendanaan dalam perusahaan. Adanya piutang berarti perusahaan mempunyai hak klaim terhadap seseorang atau perusahaan lain. Dengan adanya hak klaim ini perusahaan dapat menuntut pembayaran dalam bentuk uang atau penyerahan aset atau jasa lain kepada pihak dengan siapa ia berpiutang. Oleh karena adanya manfaat (dalam bentuk diterimanya uang tunai, aset lain atau jasa) yang diharapkan dapat diperoleh di masa datang maka piutang dianggap sebagai aset.

Berdasarkan observasi penulis di objek penelitian, permasalahan yang terjadi di CV Bumi Tiara Abadi adalah terdapat tunggakan macet/kredit macet. Hal itu disebabkan terjadi perangkapan antara fungsi keuangan dan fungsi administrasi perusahaan, sehingga menimbulkan kemungkinan terjadinya pencatatan transaksi yang tidak sebenarnya. Selain itu data akuntansi yang dhasilkan tidak dapat dipercaya kebenarannya dan mengakibatkan kekayaan organisasi tidak terjamin keamanannya. Kondisi diatas jika dibiarkan terus menerus akan mengakibatkan perusahaan mengalami penurunan laba.

\section{TINJAUAN TEORI}

\section{a. Pengendalian Intern}

Mardi (2011:60) menyatakan pengendalian intern merupakan suatu sistem yang meliputi struktur organisasi beserta semua mekanisme dan ukuran-ukuran yang dipatuhi bersama untuk menjaga seluruh harta kekayaan organisasi dari berbagai arah. Menurut James Hall dalam Mardi (2011:59) Commite on Auditing Procedure American Institute of Carified Public Accountant (AICPA) mengemukakan, bahwa pengendalian intern mencakup rencana organisasi dan semua metode serta tindakan yang telah digunakan dalam perusahaan untuk mengamankan asetnya, mengecek kecermatan dan keandalan data akuntansi, memajukan efisiensi operasi, dan mendorong ketaatan pada kebijakan yang telah ditetapkan. Sesuai dengan definisi yang dikemukakan AICPA, maka dapat dirumuskan tujuan dari pengendalian intern, yaitu 1) Menjaga keamanan harta milik perusahaan, 2) Memeriksa ketelitian dan kebenaran informasi akuntansi, 3)Meningkatkan efisiensi operesional perusahaan, 4) Membantu menjaga kebijaksanaan manajemen yang telah ditetapkan.

\section{b. Piutang}

Menurut Fahmi (2015:137) piutang merupakan bentuk penjualan yang dilakukan oleh suatu perusahaan dimana pembayarannya tidak dilakukan secara tunai, namun bersifat bertahap. Stice dan Skousen dalam IAI (2015:196) secara teori, piutang dinilai dalam jumlah yang mewakili nilai sekarang dari perkiraan penerimaan kas dimasa mendatang. Piutang yang timbul dari penjualan barang atau jasa 
secara kredit biasanya diklasifikasikan sebagai piutang usaha atau wesel tagih. Oleh karena piutang usaha berjangka pendek, biasanya ditagih dalam kurun waktu 30 sampai 90 hari, bunganya akan relatif lebih kecil dari jumlah piutangnya. Sebagai ganti dari menilai piutang usaha dari nilai sekarang yang didiskontokan, piutang dilaporkan sebagai nilai realisasi bersih (net realizable value) yaitu nilai kas yang diharapkan.

Sebagian besar piutang timbul dari penyerahan barang dan jasa secara kredit kepada pelanggan. Tidak dapat dipungkiri bahwa pada umumnya pelanggan akan menjadi lebih tertarik untuk membeli sebuah produk yang ditawarkan secara kredit oleh perusahaan (penjual) dan hal ini rupanya juga menjadi salah satu trik bagi perusahaan untuk meningkatkan besarnya omset penjualan yang akan tampak dalam laporan laba ruginya. Piutang yang timbul dari perusahaan atau penyerahan barang dan jasa secara kredit ini diklasifikasikan sebagai piutang usaha yang kemudian tidak tertutup kemungkinan akan berganti menjadi piutang wesel. Menurut Hery (2011: 36) dalam praktik, piutang pada umumnya diklasifikasikan menjadi :

\section{Piutang Usaha}

Yaitu jumlah yang akan ditagih dari pelanggan sebagai akibat penjualan barang atau jasa secara kredit. Piutang usaha memiliki saldo normal disebelah debet sesuai dengan saldo normal untuk aset. Piutang usaha biasanya diperkirakan akan dapat ditagih dalam jangka waktu yang relatif pendek, biasanya dalam waktu 30 hingga 60 hari. Setelah ditagih, secara pembukuan piutang usaha diklasifikasikan dalam neraca sebagai aset lancar (current asset).

\section{Piutang Wesel}

Yaitu tagihan perusahaan kepada pembuat wesel. Pembuat wesel disini adalah pihak yang telah berhutang kepada perusahaan baik melalui peminjaman sejumlah uang. Pihak yang berhutang berjanji kepada perusahaan (selaku pihak yang diutangkan) untuk membayar sejumlah uang tertentu berikut bunganya dalam kurun waktu yang telah disepakati. Janji pembayaran tersebut ditulis secara formal dalam sebuah wesel atau promes (promissory note). Perhatikanlah baik-baik bahwa piutang wesel mengharuskan debitur untuk membayar bunga.

3. Piutang Lain-lain

Piutang lain-lain umumnya
diklasifikasikan dan dilaporkan Contohnya adalah piutang bunga, piutang deviden (tagihan kepada investee sebagai hasil atas investasi), piutang pajak (tagihan perusahaan kepada pemerintah berupa restitusi atau pengembalian atas kelebihan pembayaran pajak), dan tagihan kepada karyawan. Agoes (2011:196) evaluasi pengendalian intern merupakan bagian yang sangat penting dalam suatu proses pemeriksaan akuntan. Karena hasil dari evaluasi pengendalian intern atas piutang berupa kesimpulan apakah pengendalian intern atas piutang dan transaksi penjualan, piutang dan penerimaan kas berjalan efektif atau tidak.

\section{c. Piutang Tak Tertagih}

Menurut Wahyuni, dkk (2013:192) piutang tak tertagih timbul 
karena adanya risiko piutang yang tidak dapat terbayar oleh debitur perusahaan karena berbagai alasan, misalnya analisis umur piutang. Semakin banyak piutang usaha yang diberikan, maka semakin banyak pula jumlah piutang tak terbayar. Keiso dan Weygend dalam Wahyuni, dkk (2013:192) mendefinisikan piutang tak tertagih sebagai berikut: "Suatu piutang tak tertagih adalah kerugian pendapatan yang memerlukan ayat pencatatan yang tepat didalam perkiraan penurunan dalam perkiraan harta piutang dan penurunan yang berkaitan dalam laba dan ekuitas pemegang saham".

Menurut Hery (2011:43), ada dua metode yang digunakan untuk menilai, mencatat, atau menghapus piutang usaha yang tidak dapat ditagih, yaitu metode hapus langsung dan metode pencadangan.

1. Metode hapus langsung

Metode ini digunakan terutama oleh perusahaan yang memilki bidang usaha seperti restoran, hotel, rumah sakit, kantor pengacara, kantor akuntan publik, toko eceran dengan skala bisnis yang relatif kecil (seperti toko yang menjual alat-alat listrik, mainan anak-anak, dan lain sebagainya). Faktor-faktor atau perihal yang membuat metode hapus langsung ini dipakai adalah : (1) terdapatnya sebuah situasi yang dimana memang sangat tidak memungkinkan bagi perusahaan untuk mengestimasi besarnya piutang usaha yang tidak dapat ditagih sampai dengan akhir periode, atau (2) khusus bagi perusahaan yang menjual sebagian besar barang atau jasanya secara tunai sehingga jumlah beban atas piutang usaha yang tidak dapat ditagih boleh dibilang sangat tidak meterial. Untuk hal yang kedua ini, tentu saja bahwa jumlah piutang usaha yang ditimbulkan dari kegiatan bisnis perusahaan hampir dapat dipastikan sangat kecil sekali.

2. Metode pencadangan

Sepanjang periode dimana penjualan kredit terjadi, estimasi mengenai besarnya piutang usaha yang tidak dapat ditagih dibuat. Pada titik ini (dalam periode penjualan), karena perusahaan belum dapat mengetahui mana dari pelanggannya yang tidak bisa membayar maka perusahaan tidak akan mengkredit (menghapus) piutang usahanya secara langsung.

Sutojo (2003:216) ada beberapa sebab yang mengakibatkan tejadinya piutang tak tertagih, yaitu :

1. Terlalu mudah memberikan kredit yang disebabkan karena tidak ada patokan yang jelas tentang kelayakan permintaan kredit yang diajukan.

2. Kurang memadainya jumlah eksekutif dan staf bagian kredit yang berpengalaman.

3. Lemahnya bimbingan dan pengawasan kepada para eksekutif dan staf bagian kredit.

4. Jumlah pemberian kredit yang melampaui batas kemampuan kredit.

5. Lemahnya kemampuan perusahaan mendeteksi kemungkinan timbulnya piutang tak tertagih.

Kerangka berpikir dalam penelitian ini adalah :

\section{Gambar 1. Kerangka Berpikir}

\begin{tabular}{|l|l|}
\hline $\begin{array}{l}\text { Pengendalian } \\
\text { Intern Piutang }\end{array}$ & $\begin{array}{l}\text { Piutang Tak } \\
\text { Tertagih }\end{array}$ \\
\cline { 2 - 2 }
\end{tabular}


Timbulnya piutang terjadi karena adanya penjualan barang atau jasa secara kredit, untuk itu penulis ingin membahas pengendalian intern piutang dalam meminimalisir piutang tak tetagih. Piutang tak tertagih dalam hal ini terkait dengan biaya pendapatan pada CV Bumi Tiara Abadi. Besarnya piutang tak tertagih yang dialami oleh CV Bumi Tiara Abadi setiap tahunnya akan berpengaruh pada kerugian bahkan kebangkrutan.

\section{PROSEDUR PENELITIAN}

\section{Menurut Sugiyono (2015:38)} variabel penelitian pada dasarnya adalah segala sesuatu yang berbentuk apa saja yang ditetapkan oleh peneliti untuk dipelajari sehingga diperoleh informasi tentang hal tersebut, kemudian ditarik kesimpulannya. Definisi operasional istilah dalam penelitian ini adalah:

Tabel 1. Definisi Operasional Istilah

\begin{tabular}{|c|c|c|}
\hline VARIABEL & DEFINISI & INDIKATOR \\
\hline $\begin{array}{l}\text { Pengendalian } \\
\text { intern piutang }\end{array}$ & $\begin{array}{l}\text { Pengendalian intern merupakan suatu } \\
\text { sistem yang meliputi struktur organisasi } \\
\text { beserta semua mekanisme dan ukuran- } \\
\text { ukuran yang dipatuhi bersama untuk } \\
\text { menjaga seluruh harta kekayaan } \\
\text { organisasi dari berbagai arah. Mardi } \\
(2011: 60)\end{array}$ & $\begin{array}{l}\text { - Internal Control } \\
\text { Questionnaires } \\
\text { - Narrative }\end{array}$ \\
\hline $\begin{array}{l}\text { Piutang } \\
\text { tertagih }\end{array}$ & $\begin{array}{l}\text { Piutang tak tertagih timbul karena adanya } \\
\text { risiko piutang yang tidak dapat terbayar } \\
\text { oleh debitur perusahaan. Wahyuni, dkk } \\
(2013: 192)\end{array}$ & - Analisis umur piutang \\
\hline
\end{tabular}

\section{Populasi dan Sampel}

Menurut Sugiyono (2015:215) populasi adalah wilayah generalisasi yang terdiri atas : objek atau subjek yang mempunyai kualitas dan karakteristik tertentu yang ditetapkan oleh peneliti untuk dipelajari dan kemudian ditarik kesimpulannya. Populasi dari penelitian ini adalah daftar piutang dan piutang tak tertagih pada CV Bumi Tiara Abadi. Sampel adalah bagian dari jumlah dan karakteristik yang dimiliki oleh populasi tersebut. Sampel dari penelitian ini adalah daftar piutang dan piutang tak tertagih pada CV Bumi Tiara Abadi dari tahun 2015 sampai dengan 2017.

\section{Metode Penelitian}

Menurut Sugiyono (2015:8) metode penelitian kuantitatif adalah metode penelitian yang berlandaskan pada filsafat positivisme digunakan untuk meneliti pada populasi atau sampel tertentu, pengumpulan data menggunakan instrumen penelitian, analisis bersifat kuantitatif/statistik dengan tujuan untuk menguji hipotesis yang telah ditetapkan. Menurut Sugiyono (2015:9) metode penelitian kualitatif adalah metode penelitian yang berlandaskan pada filsafat positivisme, digunakan untuk meneliti pada kondisi objek yang alamiah, (sebagai lawannya adalah eksperimen) dimana peneliti adalah sebagai instrument kunci, teknik pengumpulan data dilakukan secara triangulasi (gabungan), analisis data bersifat induktif/kualitatif, dan hasil penelitian kualitatif lebih menekankan makna dari pada generalisasi. Penelitian yang akan dilakukan adalah menggunakan metode penelitian kualitatif. 
IV. HASIL PENELITIAN DAN PEMBAHASAN

\section{a. Analisis Piutang Tak Tertagih pada CV Bumi Tiara Abadi}

Daftar piutang tak tertagih pada CV Bumi Tiara Abadi dari tahun 20152017 adalah sebagai berikut:

Tabel 2

Daftar Piutang dan Piutang Tak Tertagih

CV Bumi Tiara Abadi

\begin{tabular}{|c|c|c|c|}
\hline Tahun & $\begin{array}{c}\text { Total Piutang } \\
(\mathbf{R p})\end{array}$ & $\begin{array}{c}\text { Piutang Tak Tertagih } \\
\text { (Rp) }\end{array}$ & $\begin{array}{c}\text { Persentase } \\
\text { Piutang Tak } \\
\text { Tertagih } \\
\text { (\%) }\end{array}$ \\
\hline 2015 & 2.763 .054 .526 & 525.425 .979 & $19,01 \%$ \\
\hline 2016 & 6.012 .877 .109 & 117.289 .357 & $1,95 \%$ \\
\hline 2017 & 5.386 .293 .978 & 752.021 .271 & $13,9 \%$ \\
\hline
\end{tabular}

Sumber : CV Bumi Tiara Abadi, (2018)

Berdasarkan data di atas, dapat dilihat bahwa kenaikan piutang atau penjualan secara kredit tiap tahunnya terus meningkat. Namun, kenaikan piutang ini selalu diikuti oleh kenaikan piutang tak tertagih. Pada tahun 2015 persentase piutang tak tertagih $19,01 \%$ dari total piutang sebesar Rp 2.763.054.526 dan piutang tak tertagih sebesar Rp 525.425.979. Tahun 2015 persentase piutang tak tertagih 1,95\% dari total piutang mengalami kenaikan sebesar Rp 6.012.877.109, sedangkan piutang tak tertagih mengalami penurunan menjadi sebesar Rp117.289.357. Tahun 2017 persentase piutang tak tertagih 13,9\% dari total piutang mengalami penurunan sebesar Rp5.386.293.978, sedangkan piutang tak tertagih mengalami kenaikan menjadi sebesar Rp752.021.271.

Terjadinya piutang disebabkan karena adanya penjualan secara kredit (barang dagangan). Untuk mencegah piutang menjadi kredit macet, terdapat beberapa langkah-langkah yang dilakkukan perusahaan, antara lain :
Langkah 1 : Penagihan piutang pelanggan melalui surat

Pada penagihan ini guna untuk memberitahu kepada pelanggan untuk membayar piutangnya yang sudah mendekati tanggal jatuh tempo.

Langkah 2 : Penagihan piutang pelanggan melalui surat ke-2

Pada penagihan ini memberitahu kepada pelanggan bahwa waktu pembayaran piutangnya sudah melewati tanggal jatuh tempo.

Langkah 3 : Penagihan piutang pelanggan melalui telepon

Pada penagihan ini pihak perusahaan berbicara langsung kepada pelanggan mengingatkan bahwa ada piutang/tunggakan yang belum dibayar dan harus segera dilunasi karena sudah melewati tanggal jatuh tempo (1 bulan - 3 bulan).

Langkah 4 : Penagihan piutang melalui telepon ke-2

Pada penagihan ini juga pihak perusahaan mengingatkan kembali kepada pelanggan untuk membayar piutang/tunggakan secepatnya, dan 
apabila hutang/tunggakan tidak dibayar, maka pihak perusahaan akan mendatangkan pihak surveyor ke tempat pelanggan ( 3 bulan -6 bulan).

Langkah 5 : Penagihan piutang

pelanggan melalui surveyor

Pada penagihan ini pihak perusahaan mendatangkan surveyor ke tempat pelanggan dan memberitahu pelanggan untuk membayar piutang/tunggakan sekarang sebelum persoalan ini diserahkan kepada lembaga penagihan dan mungkin akan ditindak lanjuti dengan tindakan hukum (lebih dari 6 bulan).

Berdasarkan informasi yang diperoleh penulis dari perusahaan, proses terjadinya piutang tak tertagih ini disebabkan beberapa alasan atau sebab, seperti: konsumen tidak berada di tempat pada saat ditagih, usaha konsumen bermasalah sehingga tidak dapat membayar, konsumen pindah alamat, saat di survey konsumen memanggil tetangganya/pihak lain untuk mengelabui surveyor, dan lainlain. Perusahaan memberikan kebijakan dalam melakukan pengahapusan terhadap piutang pelanggan yang tidak dapat ditagih dengan alasan seperti : pelanggan meninggal dunia, pelanggan mengalami bangkrut, pelanggan mengalami masalah dalam usahanya sehingga tidak mampu lagi untuk membayar piutang/tunggakan.

\section{b. Internal Control Questinnaires (ICQ) Piutang pada CV Bumi Tiara Abadi}

Berikut ini tabel 4.2 tentang Internal Control Questinnaires (ICQ) Piutang pada CV.Bumi Tiara Abadi, (Agoes, 2011:205).

Tabel 4.2

Internal Control Questinnaires (ICQ) Piutang CV Bumi Tiara Abadi

\begin{tabular}{|c|c|c|c|c|c|}
\hline \multirow[t]{2}{*}{ No } & \multirow[t]{2}{*}{ Klien } & $\mathrm{Y}=\mathrm{Ya}$ & T=Tidak & $\begin{array}{c}\text { TR=Tidak } \\
\text { Relevan }\end{array}$ & \multirow[t]{2}{*}{ Keterangan } \\
\hline & & $\mathbf{Y}$ & $T$ & TR & \\
\hline 1. & $\begin{array}{l}\text { Apakah perusahaan membuat kartu } \\
\text { piutang? } \\
\text { Bila ya: } \\
\text { a. Apakah secara bulanan atau } \\
\text { tahunan diadakan pencocokkan } \\
\text { saldo perkiraan control (buku besar } \\
\text { piutang) dengan kartu piutang? } \\
\text { b. Apakah pengamanan fisik kartu } \\
\text { piutang cukup? } \\
\text { c. Apakah hanya orang tertentu yang } \\
\text { memegang kartu piutang? }\end{array}$ & $\begin{array}{l}\sqrt{ } \\
\sqrt{ }\end{array}$ & & & \\
\hline 2. & $\begin{array}{l}\text { Apakah pencatatan di kartu piutang: } \\
\text { a. Sering bergilir? } \\
\text { b. Terpisah dari yang mengerjakan } \\
\text { buku besar? }\end{array}$ & $\sqrt{ }$ & $\sqrt{ }$ & & \\
\hline 3. & $\begin{array}{l}\text { Apakah perkiraan piutang pelanggan } \\
\text { secara periodik diteliti mengenai : } \\
\text { a. Pelanggan yang sering terlambat? } \\
\text { b. Bukti adanya salah pembebanan? } \\
\text { c. Bukti adanya pelunasan sebagian- } \\
\text { sebagian? } \\
\text { d. Bukti adanya penghapusan yang }\end{array}$ & $\sqrt{ }$ & $\sqrt{ }$ & & \\
\hline
\end{tabular}




\begin{tabular}{|c|c|c|c|c|}
\hline & $\begin{array}{l}\text { tidak dilaporkan? } \\
\text { e. Sesuatu ketidaklaziman? }\end{array}$ & $\sqrt{ }$ & $\begin{array}{l}\sqrt{ } \\
\sqrt{ }\end{array}$ & \\
\hline 4. & $\begin{array}{l}\text { Apakah setiap bulan dikirimkan } \\
\text { rekening koran (statement of account) } \\
\text { kepada pelanggan? } \\
\text { Apabila ya: } \\
\text { a. Dicocokkan dengan kartu piutang } \\
\text { oleh orang yang tidak berhubungan } \\
\text { dengan penerimaan uang dan nota } \\
\text { kredit? } \\
\text { b. Terkontrol atas kemugkinan diubah } \\
\text { sebelum dikirim? } \\
\text { c. Diposkan/dikirim oleh orang lain dan } \\
\text { bukan petugas administrasi piutang? }\end{array}$ & & $\sqrt{ }$ & $\begin{array}{l}\text { Karena sistem } \\
\text { penagihan } \\
\text { berdasarkan perjanjian } \\
\text { di awal pembelian } \\
\text { secara kredit. }\end{array}$ \\
\hline 5. & $\begin{array}{l}\text { Apakah perselisihan dengan } \\
\text { pelanggan ditangani oleh bagian kredit } \\
\text { atau atasan yang dikuasakan dan tidak } \\
\text { dilakukan oleh kasir atau petugas } \\
\text { administrasi piutang? }\end{array}$ & $\sqrt{ }$ & & \\
\hline 6. & $\begin{array}{l}\text { Apabila perusahaan memberikan } \\
\text { potongan yang lebih besar dari } \\
\text { biasanya mendapatkan persetujuan } \\
\text { khusus dari pejabat perusahaan yang } \\
\text { berwenang? }\end{array}$ & $\sqrt{ }$ & & \\
\hline 7. & $\begin{array}{l}\text { Apakah koreksi atas faktur dan } \\
\text { penghapusan piutang harus disetujui } \\
\text { oleh manager perusahaan? }\end{array}$ & $\sqrt{ }$ & & \\
\hline 8. & $\begin{array}{l}\text { Apakah bukti untuk penagihan atas } \\
\text { piutang yang telah dihapuskan } \\
\text { diamankan untuk mencegah } \\
\text { penyalahgunaan? }\end{array}$ & $\sqrt{ }$ & & \\
\hline 9. & $\begin{array}{l}\text { Apakah secara periodik dibuat analisis } \\
\text { umur piutang dan yang sudah lama } \\
\text { jatuh tempo di follow up? }\end{array}$ & $\sqrt{ }$ & & \\
\hline 10. & $\begin{array}{l}\text { Apakah terdapat kebijakan manajemen } \\
\text { tentang penghapusan piutang? }\end{array}$ & $\sqrt{ }$ & & \\
\hline 11. & $\begin{array}{l}\text { Apakah untuk penagihan dibuatkan } \\
\text { bukti kwitansi? } \\
\text { Apabila ya: } \\
\text { a. Apakah kwitansi tersebut memiliki } \\
\text { nomor urut tercetak? } \\
\text { b. Apakah kwitansi dibuat setelah } \\
\text { diperiksa lebih dahulu ke masing- } \\
\text { masing saldo piutang? } \\
\text { c. Apakah bagian akuntansi } \\
\text { memperhatikan urutan nomornya? }\end{array}$ & & $\sqrt{ }$ & \\
\hline 12. & $\begin{array}{l}\text { Apakah penerimaan berupa cek } \\
\text { mundur/giro (post dated cheque) } \\
\text { diberikan ke bagian akuntansi? }\end{array}$ & $\sqrt{ }$ & & \\
\hline 13. & $\begin{array}{l}\text { Apakah hasil penagihan langsung } \\
\text { diserahkan kepada bagian kasir dalam } \\
\text { waktu yang tidak begitu lama dan } \\
\text { dalam jumlah yang seharusnya } \\
\text { diterima? }\end{array}$ & & $\sqrt{ }$ & $\begin{array}{l}\text { Pelanggan } \\
\text { mentransfer tagihan } \\
\text { piutang ke rekening } \\
\text { perusahaan. Jadi } \\
\text { secara otomatis hasil } \\
\text { tagihan langsung } \\
\text { masuk ke perusahaan } \\
\text { melalui bagian } \\
\text { akuntansi. }\end{array}$ \\
\hline
\end{tabular}




\begin{tabular}{|l|l|l|l|l|l|}
\hline 14. & $\begin{array}{l}\text { Apakah pada cek mundur yang } \\
\text { diterima telah dicantumkan nama } \\
\text { perusahaan/klien? }\end{array}$ & $\sqrt{ }$ & & \\
\hline $15 . \quad \begin{array}{l}\text { Apakah bagian akuntansi mengadakan } \\
\text { jurnal khusus untuk penerimaan cek } \\
\text { mundur? }\end{array}$ & $\sqrt{ }$ & & & \\
\hline $\begin{array}{l}\text { Kesimpulan penilaian (baik, sedang, } \\
\text { buruk) }\end{array}$ & \multicolumn{2}{|c|}{ BAIK } \\
\hline $\begin{array}{l}\text { Diisi oleh : } \\
\text { Manajemen CV Bumi Tiara Abadi Palembang } \\
\text { Tanggal : } 21 / 11 / 2017\end{array}$ & & & & \\
\hline $\begin{array}{l}\text { Direview oleh : } \\
\text { Tan.................. }\end{array}$ & & & & \\
\hline
\end{tabular}

Sumber : CV Bumi Tiara Abadi, 2018

\section{c. Analisis Internal Control Questinnaires (ICQ) Piutang Bumi Tiara Abadi \\ Berdasarkan dari Internal Control} Questinnaires (ICQ) di atas, berikut ini analisis yang dapat diberikan oleh penulis, antara lain:

1. Perusahaan hanya membuat kartu piutang dalam pencatatan piutang, terpisah dari yang mengerjakan buku besar.

2. Pencatatan di kartu piutang hanya dilakukan oleh bagian penjualan dan pencatatannya terpisah dari buku besar.

3. Perkiraan piutang pelanggan harus di analisis karena perusahaan ingin memastikan pelanggan mana saja yang sering terlambat dan lancar dalam membayar piutang.

4. Bank tidak mengirimkan rekening koran kepada perusahaaan, karena sistem penagihan perusahaan sudah dibuat berdasarkan perjanjian lisan di awal pengambilan barang dagang.

5. Dalam perselisihan piutang dengan pelanggan, manajemen perusahaan menyerahkannya kepada bagian kredit untuk menangani/mengatasinya.

6. Untuk pemberian potongan penjualan yang lebih besar langsung oleh atasan atau manajemen yang menanganinya, karena yang mengelola/mengatur dalam penjualan kredit adalah atasan atau manajemen perusahaan.

7. Dalam koreksi faktur dan penghapusan piutang diatur langsung oleh atasan atau manajemen sesuai dengan SOP perusahaan.

8. Untuk penagihan atas piutang yang telah dihapuskan perusahaan harus berhati-hati untuk mencegah penyalahgunaan atau kecurangan.

9. Perusahaan akan memfollow up secara periodik umur piutang yang sudah jatuh tempo, karena untuk mengetahui piutang-piutang pelanggan yang macet dan lancar.

10. Perusahaan mengeluarkan kebijakan penghapusan terhadap piutang dengan alasan seperti: pelanggan meninggal dunia, pelanggan mengalami bangkrut atau pelanggan mengalami masalah dalam usahanya sehingga tidak mampu lagi membayar piutang/tunggakan.

11. Perusahaan tidak membuat bukti kwitansi karena dalam penagihan perusahaan sudah ada kartu piutang untuk mengetahui masingmasing piutang pelanggan yang bersangkutan.

12. Dalam penerimaan berupa cek mundur perusahaan akan memberikan ke bagian akuntansi 
untuk mencatat terlebih dahulu sebelum dilaporkan.

13. Untuk penagihan piutang, pelanggan mentransfer pembayaran piutangnya langsung ke rekening perusahaan. Jadi secara otomatis hasil tagihan langsung masuk ke rekening perusahaan.

14. Dalam pencatatan cek mundur, perusahaan hanya menerima cek yang sudah tercantum nama perusahaan/klien yang bersangkutan.

15. Proses pencatatan cek mundur perusahaan menggunakan jurnal khusus, dengan tujuan mempermudah proses pencatatan.

\section{d. Kajian Penulis Terhadap Internal Control Questinnaires (ICQ) Piutang Pada CV Bumi Tiara Abadi}

Berdasarkan hasil dari Internal Control Questinnaires (ICQ) Piutang di atas, maka penulis memisahkan antara kuesioner yang telah memenuhi ketentuan dan yang belum memenuhi ketentuan pengendalian intern atas piutang pada CV Bumi Tiara Abadi :

1. Internal Control Questinnaires (ICQ) piutang yang memenuhi ketentuan pengendalian intern pada CV Bumi Tiara Abadi, yaitu :

a. Pencatatan di kartu piutang hanya dilakukan oleh bagian penjualan dan pencatatannya terpisah dari buku besar.

b. Perkiraan piutang pelanggan harus di analisis karena perusahaan ingin memastikan pelanggan mana saja yanng sering terlambatdan lancara dalam membayar piutang.

c. Dalam perselisihan piutang dengan pelanggan, manajemen perusahaan menyerahkannya kepada bagian kredit untuk menangani/mengatasinya. d. Untuk pemberian potongan penjualan yang lebih besar langsung oleh atasan atau manajemen yang menanganinya, karena yang mengelola/mengatur dalam penjualan kredit adalah atasan atau manajemen perusahaan.

e. Dalam koreksi faktur dan penghapusan piutang diatur langsung oleh atasan atau manajemen sesuai dengan SOP perusahaan.

f. Untuk penagihan atas piutang yang telah dihapuskan perusahaan harus berhati-hati untuk mencegah penyalahgunaan atau kecurangan.

g. Perusahaan akan memfollow up secara periodik umur piutang yang sudah jatuh tempo, karena untuk mengetahui piutangpiutang pelanggan yang macet dan lancar.

h. Perusahaan mengeluarkan kebijakan penghapusan terhadap piutang dengan alasan seperti : pelanggan meninggal dunia, pelanggan mengalami bangkrut, pelanggan menngalami masalah dalam usahanya sehingga tidak mampu lagi membayar piutang/tunggakan.

i. Dalam penerimaan berupa cek mundur, perusahaan akan memberikan ke bagian akuntansi untuk mencatat terlebih dahulu sebelum dilaporkan.

j. Untuk penagihan piutang, pelanggan mentransfer pembayaran piutangnya langsung ke rekening perusahaan. Jadi secara otomatis hasil tagihan langsung masuk ke rekening perusahaan.

k. Dalam pencatatan cek mundur, perusahaan hanya menerima cek yang sudah tercantum nama 
perusahaan/klien

yang

bersangkutan.

I. Proses pencatatan cek mundur perusahaan menggunakan jurnal khusus, dengan tujuan mempermudah proses pencatatan.

2. Internal Control Questinnaires (ICQ) piutang yang belum memenuhi ketentuan pengendalian intern pada CV Bumi Tiara Abadi, yaitu :

a. Perusahaan hanya membuat kartu piutang dalam pencatatan piutang, terpisah dari yang mengerjakan buku besar.

b. Bank tidak mengirimkan rekening koran kepada perusahaaan, karena sistem penagihan perusahaan sudah dibuat berdasarkan perjanjian lisan di awal pengambilan barang dagang.

c. Perusahaan tidak membuat bukti kwitansi karena dalam penagihan perusahaan sudah ada kartu piutang untuk mengetahui masing-masing piutang pelanggan yang bersangkutan.

Berdasarkan hasil dari Internal Control Questinnaires (ICQ) piutang yang belum memenuhi ketentuan pengendalian intern pada CV Bumni Tiara Abadi, maka ada beberapa hal yang harus dibenahi oleh perusahaan yaitu :

a. Dalam melakukan pengendalian piutang, sebaiknya perusahaan tidak hanya menggunakan kartu piutang saja, tetapi perusahaan harus membuat siklus akuntansi untuk pencatatan piutangnya.

b. Rekening koran yang dikeluarkan oleh bank sangat penting dimiliki perusahaan, untuk mempermudah mengecek pelanggan yang lancar dan tidak lancar dalam pembayaran piutangnya.

c. Perusahaan membuat bukti pembayaran berupa kwitansi sebagai tanda bukti bahwa pelanggan telah melunasi piutangnya.

\section{PENUTUP}

\section{Kesimpulan}

Berdasarkan dari hasil pembahasan mengenai sistem pengendalian intern piutang dalam meminimalisir piutang tak tertagih pada CV Bumi Tiara Abadi, dapat disimpulkan bahwa terdapat beberapa hal yang belum memenuhi ketentuan pengendalian intern, yaitu :

1. Perusahaan hanya membuat kartu piutang dalam pencatatan piutang, terpisah dari yang mengerjakan buku besar.

2. Perusahaan tidak menggunakan rekening koran yang dikeluarkan oleh bank dalam pengecekkan jumlah piutang pelanggan.

3. Perusahaan tidak membuat bukti kwitansi kepada pelanggan yang sudah membayar piutangnya.

\section{Saran}

Dari hasil pembahasan yang telah dilakukan, penulis mencoba memberi saran sebagai bahan masukan bagi CV Bumi Tiara Abadi mengenai ketentuan pengendalian intern, antara lain :

1. Dalam melakukan pengendalian piutang, sebaiknya perusahaan tidak hanya menggunakan kartu piutang saja, tetapi perusahaan harus membuat siklus akuntansi (jurnal dan buku besar) agar pencatatan piutang menjadi lebih baik.

2. Rekening koran yang dikeluarkan oleh bank sangat penting dimiliki 
perusahaan, untuk mempermudah mengecek pelanggan yang lancar dan tidak lancar dalam pembayaran piutangnya.

3. Perusahaan harus membuat bukti pembayaran berupa kwitansi sebagai tanda bukti bahwa pelanggan telah melunasi piutangnya.

\section{DAFTAR PUSTAKA}

Agoes, Sukrisno, 2011. Auditing Edisi Keempat, Penerbit : Salemba Empat, Jakarta.

Fahmi, Irham, 2015. Pengantar Manajemen Keuangan, Penerbit : Alfabeta, Bandung.

Hery, 2011. Akuntansi Aktiva, Utang, dan Modal, Penerbit : Gava Media, Yogyakarta.

IAI Sumsel, 2015. Pengantar Akuntansi Berbasis SAK ETAP, Penerbit : Ikatan Akuntan Indonesia Wilayah Sumatera Selatan, Palembang.
Mardi, 2011. Sistem informasi Akuntansi, Penerbit : Ghalia Indonesia, Bogor.

Mulyadi, 2006. Auditing Jilid 2, Edisi Revisi, Penerbit : Salemba Empat, Jakarta.

Sugiyono, 2015. Metode Penelitian Kuantitatif Kualitatif dan $R \& D$, Penerbit : Alfabeta, Bandung.

Sutojo, Siswanto, 2003. Akuntansi Piutang, Penerbit : Salemba Empat, Jakarta.

Wahyuni, Indriwati Tri, Rosyafah, Siti, dan Rasyidi, Ali, 2013. Penerapan Sistem Akuntansi Penjualan Kredit Dalam Meningkatkan Pengendalian Intern Piutang Tak Tertagih Pada Bengkel Bonex. Jurnal Akuntansi UBHARA ISSN 2460-7762 Volume 1, Nomor 10, Oktober 2013. Fakultas Ekonomi Universitas Bhayangkara Surabaya 